\title{
When Did Ibn Isḥāq Compose His maghāzī?
}

\author{
Michael Lecker
}

It is widely assumed that Ibn Ishāq (d. c.151/768) wrote Muhammad's biography at the behest of the second Abbasid caliph Abū Ja'far al-Manșūr (r. 136-158/75475).

Wim Raven wrote:

Pivotal in the biographical literature is Muhammad b. Ishāq [...]. After having left his native Medina for Iraq, he was asked by the caliph alManșūr (r. 136-158/754-75) to write an all-encompassing history [...]. Ibn Ishạq did not merely collect materials; he composed a structured work, arranged sometimes chronologically and sometimes by subject matter. ${ }^{1}$

\section{Gregor Schoeler wrote:}

It was only at al-Manșūr's behest that he recorded his collection in his exhaustive syngrammatic historical work, the Kitāb al-kabìr (or Kitāb

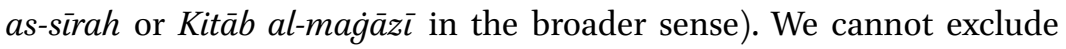
the (never explicitly documented) possibility that Ibn Ishāq had already redacted parts of his collections [...] as a coherent narration and transmitted the material in this form before the intervention of the caliph. But we can establish on the basis of our sources that, before the redaction for the court, the publication of his material was restricted to his personal lectures, whereas he now, for the first time, produced a proper book for use by lay people (albeit only a small court circle) ${ }^{2}$

1 Wim Raven, "Biography of the Prophet," in Encyclopaedia of Islam THREE, accessed 1 October 2017, http://dx.doi.org/10.1163/1573-3912_ei3_COM_23716 (According to Raven, "Ibn Hishām's selections" were the first sirra text to be transmitted in a fixed form). See also Muhammad Qasim Zaman, Religion and Politics under the Early Abbāsids: The Emergence of the ProtoSunnī Elite (Leiden: Brill, 1997), 157: "Ibn Isḥāq (d. 15o/767) had written his Sìra of the Prophet under the patronage of al-Manșūr."

2 Gregor Schoeler, The Biography of Muhammad: Nature and Authenticity (New York and London: Routledge, 2011), 29. 
Recently Sean Anthony wrote:

Although he hailed from Medina, Ibn Isḥāq compiled and transmitted his works, in particular his works on the Prophet's biography, exclusively in Iraq (Hīra, Baghdād), the Jazīra (Harrān), and Rayy, due to, on the one hand, the networks of patronage he enjoyed there from the 'Abbāsids and, on the other, the controversies surrounding him in his native Medina. $^{3}$

A century ago Josef Horovitz took a close look at the evidence:

That Ibn Ishāāq wrote his Kitāb al-maghāzī for the caliph [...] cannot anyhow mean that he composed it on a commission from the caliph. The list of authorities cited by him, of itself, shows that he had composed his material principally on the basis of the traditions collected by him in Medina, as well as on the basis of those that he had collected in Egypt; on the other hand, he nowhere names the authorities of Iraq. The work was obviously completed when Ibn Ishāq left the city of his fathers [italics added-M.L.] and we know also a Medinan who passes on the work of Ibn Ishāq: Ibrāhīm b. Sacd (d. 184[/8oo]). It may still, none the less, be supposed that Ibn Ishāq undertook some supplementary alterations in his work for love of the caliph, or that he suppressed passages that he feared might be displeasing to the caliph. ${ }^{4}$

\section{Ibn Sa'd's Account of the Course of Ibn Ishāà's Life}

Because there is a gap at this point in the Leiden edition of Ibn Sa'd's (d. 230/ 845) famous biographical dictionary, Horovitz had no access to Ibn Ishạa's fuller entry, ${ }^{5}$ and he could not quote it in support of his argument about the early composition of Muhammad's biography. (Appendices I \& II include the abridged entry which was available to Horovitz, followed by the fuller entry available to us now.)

3 Sean Anthony, "Muḥammad, Menaḥem, and the Paraclete: New Light on Ibn Isḥāq's (d. 15o/ 767) Arabic Version of John 15:23-16:1," Bulletin of the School of Oriental and African Studies 79 (2016): 264 .

4 Josef Horovitz, The Earliest Biographies of the Prophet and Their Authors, ed. Lawrence I. Conrad (Princeton: Darwin Press, 2002), 79-80.

5 See on this gap Schoeler, Biography, 153, n. 118. 
Ibn Sa'd was well-placed to obtain reliable information about Ibn Ishāq: first, they belonged to the same social network of mawāt associated with the Abbasid court; second, one of Ibn Sa'd's informants was a son of Ibn Ishāa.

Ibn Ishāa's association with the Abbasid court is well known, as is the fact that Ibn Sadd was a mawlā of the Banū Hāshim (for more details see Appendix III). Ibn Sa'd was al-Wāqidī's (d. 207/822) secretary, perhaps in the latter's capacity as qadi in the Abbasid capital Baghdad. Just like Ibn Ishāa, who was born some fifty years earlier, al-Wāqidī left Medina to join the Abbasids. In his entry on Ibn Ishāā, Ibn Sacd quotes a son of Ibn Isḥāq whose name is not mentioned. The son told Ibn Sa'd that his father had died in Baghdad in 150/767 and had been buried in Maqābir al-Khayzurān. ${ }^{6}$ Ibn Sad remarked however that according to other learned men ('ulama $\vec{a}^{37}$ ), Ibn Ishāa died in 151/768. Ibn Ishāā's son may well have provided Ibn Sa'd with other details about his father.

The passages of the fuller entry in Ibn Sa'd's biographical dictionary that concern us in connection with the composition of the maghāzi are the following:

Ibn Ishāa was the first who collected (jama'a) and compiled (allafa) the maghāzì of the Messenger of God [...]. He left Medina early (qadiman), and hence none of them [i.e. the Medinans] except Ibrāhīm ibn Sa'd had transmitted from him. Muḥammad ibn Ishạa was with 'Abbās ibn Muhammad in the Jazīra. Beforehand he had gone (wa-kāna atā) to Abū Ja'far in Hīra and had written for him (kataba lahu) the maghāzì. For this reason the people of Küfa learned ["heard"] from him, and the people of the Jazīra also learned ["heard"] from him when he was with 'Abbās ibn Muhammad. He also came to Rayy, and [hence] the people of Rayy too learned ["heard"] from him. Consequently, his transmitters from these places are more numerous than the people of Medina who transmitted from him.

The arrangement of Ibn Ishāq's itinerary is somewhat confusing, because the Jazīra appears before Hiìra, although Ibn Ishạa went first to Ḥira. The confusion was probably caused by poor editorial work on Ibn Sa'd's part. This is also evident in the inconsistency regarding Ibn Isḥāq's Medinan transmitters. On

6 Al-Khayzurān, the mother of Hārūn al-Rashīd and al-Hādī, was buried in the cemetery named after her. It is today in the A'żamiyya quarter in east Baghdad; Ibn Sa'd, al-Tabaqātal-kubrā:alqism al-mutammim li-tābici ahl al-Madīna wa-man ba'dahum, ed. Ziyād Muhammad Manșūr (Medina: Maktabat al-'Ulūm wa-l-Ḥikam, 1408/1987), 402, n. 5 .

7 I.e. Ibn Ishāà's son was probably an 'ālim himself, which is hardly surprising given his family background. 
the one hand, we are told that Ibn Isḥāq left Medina "early," and hence only one Medinan, namely Ibrāhīm b. Sa'd, transmitted from him. On the other hand, having told us about Ibn Ishāà's journeys, Ibn Sa'd concludes that consequently his transmitters from the places he visited were more numerous than the Medinans who transmitted from him. In fact there were several Medinan transmitters. ${ }^{8}$ However, Ibrāhim, who was a wealthy man, possibly owned the only full recension of Ibn Ishāq's maghāzì. One has to bear in mind that the production of a complete copy of a book-especially one that was transmitted piecemeal over many sessions_-involved a major investment of time and money.

The course of Ibn Ishāa's's life as outlined by Ibn Sad is significant because the entry, for all its weaknesses, is arranged chronologically (as one would expect in a biographical dictionary). First Ibn Sa'd mentions Ibn Isḥāq's collection (of accounts) and his compiling of the maghāzi. Then he mentions some of Ibn Isḥāq's sources—all of those listed—Āṣim b. 'Umar b. Qatāda (d. ca. 120/738), Yazīd b. Rūmān (d. 13o/748), Muḥammad b. Ibrāhīm [ibn al-Ḥārith al-Taymī] (d. 120/738) and Fāțima bt. al-Mundhir b. al-Zubayr (d. unknown) — were Medinans, as has already been noticed by Horovitz. Then comes Ibn Ishāq's early departure from Medina (qadìman). Ibn Sa'd does not mention Ibn Isḥāq's journey to Egypt in $115 / 733,{ }^{9}$ following which he returned to Medina. Then there are journeys to Hīra (after al-Manșūr's accession in 136/754), to 'Abbās b. Muhammad (d. 186/8o2) in the Jazīra (not before 142/759, the year of 'Abbās's appointment as governor), ${ }^{10}$ to Rayy, and finally death and burial in Baghdad.

Ibn Sa'd's outline, which places the composition of the maghāzi before the departure from Medina, is trustworthy precisely because it is at the background of the entry-it is taken for granted. Ibn Sa'd's focus is not on the date of composition, but on Ibn Ishāà's activity as a muhaddith and the opinions of other scholars regarding his reliability.

Muțāc al-Ṭarābīshī, Ruwāt Muhammad ibn Isḥāq ibn Yasār fì l-maghāzī wa-l-siyar wa-sā̉ir al-marwiyyāt (Beirut: Dār al-Fikr al-Mu'āṣir \& Damascus: Dār al-Fikr, 1414/1994), 67 defines Ibrāhīm as al-madanī al-ashhar fì aṣhāb ibn Ishạa q al-madaniyyīna. He counted more than ten Medinans who transmitted from Ibn Isḥāq; al-Ṭarābīshī, Ruwāt Muḥammad, 72. Ibn Sa'd's statement that Ibn Ishạa was the first to write a biography of Muhammad is problematic but cannot be discussed here.

9 Mizzī, Tahdhīb al-kamāl, ed. Bashshār 'Awwād Márūf (Beirut: al-Risāla, 1405/1985-1413/ 1992), 24:424.

10 Tabarī, Tảrïkh al-rusul wa-l-mulūk, eds. Michael Jan de Goeje et al. (Leiden: Brill, 18791901), I-3:141. The source is Wāqidī. 'Abbās remained in office until his dismissal in 155/772; Ṭabarī, Ta'rīkh, 374. In the same year Mūsā ibn Ka`b was appointed 'alā harb al-jazīra wakharājihā; Ṭabarī, 375 . 
More support for Ibn Ishạa's composition of the maghāzī prior to his departure from Medina is gained from a boastful statement attributed to his above mentioned disciple, Ibrāhīm b. Sa d. ${ }^{11}$ Ibrāhīm's son, Ya qūb (d. 208/823), unsuspiciously told Ahmad b. Hanbal (d. 241/855) about the following saying of his father: "Muhammad b. Isḥāq 'undid' the maghāzī three times, and I observed and witnessed all of this" (naqada Muḥammad ibn Isḥāq al-maghāziya thalāth marrāt, kull dhālika ashhaduhu wa-ahduruhu). ${ }^{12}$ According to Lane's ArabicEnglish Lexicon, naqada means, inter alia, he undid it, unwove it, rendered it uncompact, unsound or unfirm, after having made it compact, sound, or firm;-—namely a building/structure/rope/cord/silk/flax/cloth. Naqada al-bina ${ }^{\text {' }}$ min ghayr hadm means he took to pieces the building without demolishing, or destroying it.

It is worth emphasising that Ibn Ishạa himself, and not one of his disciples, was responsible for the composition of all four versions of the book-the fourth version was the one created when he "undid" the third. One assumes that several months or even years elapsed between one "undoing" and another, and it follows that the book had been composed long before Ibn Ishāa left Medina.

Ibrāhīm did not mean to criticise his venerated teacher-the background of his statement is the competition with other recensions of Ibn Ishāa's book. His recension was the earliest one, and naturally the later the recension, the better it reflected Ibn Ishạq's most up-to-date version. The "undoings" supported Ibrāhīm's claim for the accuracy of his recension: he repeatedly learned Ibn Isḥāq's book, while the latter was revising it. In other words, he had several opportunities to correct his recension and weed out its errors. Indeed 'Alī b. alMadīnìs (d. 239/853) comments that "none of the books transmitted from Ibn Ishāq is more accurate (așaḥh) than the book[s, i.e. recensions] of Ibrāhīm b. Sa'd and Hārūn al-Shāmī (d. unknown)." Regarding the latter's recension 'Alī remarks: "This is so because Ibn Isḥāq dictated to Hārūn from his own book."13

11 Ṭarābīshī, Ruwāt, 66-104 begins with Ibrāhīm his discussion of Ibn Ishāạ's transmitters and dedicates to him and to his recension a comprehensive study.

Aḥmad ibn Ḥanbal, al-Tlal wa-ma'rifat al-rijāl riwāyat ibnihi 'Abdillāh, ed. Wașī Allāh ibn Muhammad 'Abbās (Riyadh: Dār al-Khānī, 1422/2001), 3:436. A version found in another edition of the same book by the same editor (Bombay: al-Dār al-Salafiyya, 1408/1988), 55 has it that besides "undoing" the maghāzì, Ibn Isḥāq also changed them: qāla Yáqūb: sami'tu abìyaqūlu: samitu al-maghāziya minhu thalāth marrāt yanquḍhā [printed: yanqușuhā] wa-yughayyiruhā.

13 Ṭarābīshī, Ruwāt, 232. Hārūn was Ibn Isḥāq's kātib and disciple; Ṭarābīshī, 231-234. 
Ahmmad ibn Ḥanbal rather cynically used Ibrāhīm's statement out of context in order to cast doubt on Ibn Ishāa's reliability as a muhaddith. Another version of Ahmad b. Ḥanbal's verdict has a five-point appraisal of Ibn Ishạā, one of which is his "undoings." Ahmad starts with a general positive evaluation, immediately followed by four reservations: "His hadith transmission is fine (huwa hasan al-hadīth), but when he combined [in one report hadith he had received] from two men (jama'a 'an rajulayn) ..." At this point Ahmad paused. But his interlocutor insisted, so Ahmad went on: "He transmitted hadith from al-Zuhrī (d. 124/742) and from another person, ascribing the hadith of one of them to the other." This looks like two different accusations. In any case, Ahmad rejected the practice of creating Combined Reports, which was common in historiography but was anathema in the realm of legal hadith. The second reservation is the one discussed here: "Ya'qūb [Ibrāhīm b. Sa'd's son] said: 'I heard my father say: I learned ["heard"] from him the maghāzi three times, [since] he used to undo and change them'." Ahmad continued: "Mālik [b. Anas] (d. 179/796) said with reference to him [Ibn Isḥāq]: 'He was a liar' (dajjāl)." Ahmad concluded his appraisal with a comment of his own: "Muhammad b. Isḥāq came to Baghdad and was indiscriminate in his choice of informants. He would quote $(y a h k \bar{\imath})$ from al-Kalbī (d. 146/763) and others [i.e. similarly untrustworthy scholars]."14

Ahmad sensibly expects a reliable muhaddith to keep repeating precisely the same hadith under all circumstances. Still, he was aware of the fact that Ibn Ishāà's work on maghāzi (unlike Ibn Isḥāq's work on legal hadith) did not require the highest standards of transmission. Elsewhere we read that when Aḥmad was asked about Ibn Ishāan, he stated that people wrote "these hadiths" from him—meaning "maghāzi and the like." In legal matters, Ahmad explained, standards were much higher: "When something comes to you which concerns what is lawful and forbidden, we want people who are like this," and he drew together the fingers of both hands except for the thumb..$^{15}$ His gesture was meant to convey uncompromising firmness. In other words, Ahmad acknowledged that in "genres" other than legal hadith lower standards were adequate.

14 Min kalām Aḥmad ibn Ḥanbal fì 'ilal al-ḥadīth wa-márifat al-rijāl, ed. Șubḥī al-Badrī alSāmarrā'ī (Riyadh: Maktabat al-Maārif, 1409), 49. A cursory check shows that Ibn Ishāq quotes al-Kalbī referring to him both by his nisba al-Kalbī and by his kunya Abū al-Naḍr. Cf. Harry Munt, "Writing the History of an Arabian Holy City: Ibn Zabāla and the First Local History of Medina," Arabica 59 (2012): 17-18.

15 Michael Lecker, "Wāqidī's Account on the Status of the Jews of Medina: A Study of a Combined Report," Journal of Near Eastern Studies 54 (1995): 23-24. 
In the background of Ibrāhīm's statement there must have been an undisputed fact, namely the existence of Ibn Ishāq's book which predated his departure from Medina. This is the premise of his claim for the accuracy of his recension. Owners of other recensions of Ibn Ishāa's book vouched for the accuracy of their recensions with reference to the method by which they received them from Ibn Ishạa, with two of them claiming to have received their recensions twice. ${ }^{16}$

Presumably Ibn Ishāāq's work acquired book form early on in his career. ${ }^{17} \mathrm{But}$ the version that emerged from the Medinan "undoings" was not the end of the road for the book, which continued to evolve (due to new evidence, new analysis or new political circumstances). As long as Ibn Isḥāq was alive there was probably no "conclusively edited copy." At different stages of his life Ibn Isḥāq taught different versions of it. The recensions of his disciples were "reports of work in progress," or milestones along Ibn Ishāā's lifetime project on the life of Muhammad.

The Abbasids were not indifferent to the way in which the biography of Muhammad was taught, especially with regard to the problematic role of his uncle and their ancestor, 'Abbās (d. 32/653). Their close ties with Ibn Ishāā, al-Wāqidī, Ibn Sa'd and other players in the field of historiography were no accident. The same is true for their relationship with Ibrāhīm b. Sacd, for which we have both factual evidence and anecdotes. Anecdotes are useful because of the reliable background information they contain. Sometimes they provide an insight into the boundaries of tolerance in early Islamic literature.

\section{Schoeler, Biography, 28, 32.}

17 Cf. Amikam Elad, "The Beginnings of Historical Writing by the Arabs: The Earliest Syrian Writers on the Arab Conquests," Jerusalem Studies in Arabic and Islam 28 (2003): 65-152, esp. 116-128. The rich textual evidence in this fundamental and inspiring article is new to the research literature. Cf. also Amikam Elad, "Community of Believers of 'Holy Men' and 'Saints' or Community of Muslims? The Rise and Development of Early Muslim Historiography," Journal of Semitic Studies 47 (2002): 267-278. On p. 268, n. 63 of the latter article Elad quotes Meir Jacob Kister, "The Sirra Literature," in The Cambridge History of Arabic Literature: Arabic Literature to the End of the Umayyad Period, eds. Alfred Felix Landon Beeston, Thomas Muir Johnstone, Robert Bertram Serjeant and Gerald Rex Smith (Cambridge: Cambridge University Press, 1983), 352: "Sirah literature [...] came into being in the period following the death of the Prophet. It developed in the first half of the first century of the hijrah and by the end of that century the first full-length literary compilations were produced." 
As a great-grandson of Muḥammad's companion 'Abd al-Raḥmān ibn 'Awf (d. 32/653), Ibrāhīm ibn Sa'd was a member of a rich and influential family from the Zuhra branch of Quraysh. He had lived in Medina and later moved to Baghdad, where he was put in charge of the treasury (bayt al-māl). So far the factual evidence; the following is anecdotal. Ibrāhīm was a free spirit: he loved music and is said to have issued a fatwa sanctioning it. When one of the aṣhāb al-hadìth came to learn from him the hadith of Ibn Shihāb al-Zuhrī, he heard him singing and vowed never to learn from him. Without hesitation Ibrāhīm pledged that as long as he was in Baghdad, he would not transmit a single hadith unless he sang beforehand. When Hārūn al-Rashīd (r. 170/786193/8o9) asked Ibrāhīm about a certain hadith, the latter required that an oud be brought to him, which the caliph found amusing. Hārūn al-Rashīd was even more amused by a story which Ibrāhīm told him on the authority of his father, Sa'd (d. ca. ${ }^{125^{18}}$ ), about how Mālik b. Anas had clumsily tried his hand at making music. ${ }^{19}$

Obviously, Ibrāhīm belonged to the caliph's inner circle. It also appears that Mālik, a bitter adversary of Ibrāhīm's teacher Ibn Ishạà, was unpopular in Hārūn's court. It may be relevant for us here that just like Ibn Isḥāq, Ibrāhīm's father cast doubt on Mālik's claim to be a freeborn Arab. ${ }^{20}$ The father was himself an influential figure in the Abbasid administration. He was the shurța chief and then he officiated several times as qadi of Medina. ${ }^{21}$ The governors employed him as a tax collector ( $a^{\prime} m a \bar{l}$ al-ṣadaqāt $) .{ }^{22}$

18 Ibn 'Asākir, Ta’rīkh madīnat Dimashq, ed. 'Umar b. Gharāma al-'Amrawī (Beirut: Dār alFikr, 1415/1995-1421/2000), 20:208-209.

19 al-Khațīb al-Baghdādī, Ta’rīkh Baghdād, ed. Bashshār 'Awwād Márūf (Beirut: Dār al-Gharb al-Islāmī, 1422/2001), 6:6o6.

20 Meir Jacob Kister, "The Massacre of the Banū Qurayza: A Re-examination of a Tradition," Jerusalem Studies in Arabic and Islam 8 (1986): 77. Mālik wanted to be a singer, but his mother told him that nobody listened to a singer with an ugly face. She advised him to turn to the field of figh, where an ugly face made no difference; Ignaz Goldziher, Muslim Studies, ed. Samuel Miklos Stern, trans. C.R. Barber and S.M. Stern (London: George Allen \& Unwin, 1967-1971), 2:82, n. 2; Abū al-Faraj al-Ișfahānī, Kitāb al-Aghānī (Cairo: Dār al-Kutub, 1345/1927-1394/1974), 4:222. See also Abū al-Alā’ al-Ma'arrī, Risālat al-ghufrān, ed. Bint al-Shāți' (Cairo: Dār al-Macārif, 1950), 5o1. Mālik was bald (aṣlac); Ibn Farḥūn al-Mālikī, alDībāj al-mudhahhab fìma' rifat a'yān 'ulamā' al-madhhab, ed. Ma’mūn al-Jannān (Beirut: Dār al-Kutub al-'Ilmiyya, 1417/1996), 59. Sa'd did not transmit hadith in Medina, and therefore its people, including Mālik, did not write his hadith; Mizzī, Tahdhīb al-kamāl, 10:244. Ibn 'Asākir, Ta'rīkh Dimashq, 20:206. He is sometimes referred to in isnāds as Sa'd ibn Ibrāhīm al-qā ḍī. See e.g. Dhahabī, Siyar a lām al-nubalā', eds. Shu'ayb al-Arnāwūṭ et al. (Beirut: al-Risāla, 1401/1981-1409/1988), 4:293. He was qadi of Medina at the time of Qāsim b. Muḥammad b. Abī Bakr al-Ṣiddīq; Mizzī, Tahdhīb al-kamāl, 10:241. See the entry on Qāsim in Mizzī, Tahdhīb al-kamāl, 23:427-436. 
Here belong two dubious accounts which link the Abbasids to the creation of Ibn Ishāa's's biography. One account gives the credit to the caliph al-Mahdī (r. 158/775-169/785) but this is impossible, since al-Mahdi only ascended the throne several years after Ibn Ishāa's death. Allegedly the caliph demanded that Ibn Ishāq compose for his (the caliph's) son a book covering the history of the world from its creation to their own time. The book that ensued was too large, so the caliph demanded a summary "which is this abridged book." The large book was stored in the treasury. ${ }^{23}$ The glaring error regarding the caliph's identity casts doubt on the account's reliability as a whole.

The other account is included in a passage from al-Mas'ūdī's (d. 345/956) Murüj al-dhahab which, while praising the endeavours of the intellectual caliph al-Manșur, implies that he was somehow associated with the creation of Ibn Isḥāq's book:

In his days Ibn Ishāa composed (waḍa'a) the book[s, read kutub instead of kitāb-or rather the sections of a modular "history" book which also existed as independent books] of maghāzí, siyar and akhbār al-mubtada' which had neither been collected beforehand, nor known nor classified (wa-lam takun qabla dhālika majmū'a wa-lā márū fa wa-là mușannafa) ${ }^{24}$

The passage as a whole is more panegyric than history. Ibn Isḥāq may well have produced a book for the caliphal library, but it was merely a copy (or rather a revised copy) of a book he had composed long before he arrived at the Abbasid court. The caliphal copy must have been more elegant than all of the recensions, past or future. It also had another advantage: since its production was overseen by Ibn Isḥāq himself, it was free of the additions which Ibn Isḥāq's disciples attached to their recensions. In this sense it continued the line of the versions that came out of the Medinan "undoings."

PS. I now realise that C. Brockelmann, in his Geschichte der arabischen Litteratur $(G A L)$, stated that Ibn Ishāq completed the biography in Medina-and that al-Manșūr played no role in its compilation. For an English translation see now C. Brockelmann, History of the Arabic Written Tradition (Leiden: Brill, 2016-2018), Supplement, 1: 202: "He studied hadith, and completed his learn-

23 al-Khațīb al-Baghdādī, Tảrīkh Baghdād, 2:16. Al-Khațīb suggests that al-Mahdī should be replaced by al-Manșūr. Al-Mahdī's return from Rayy in 151/768 (Fasawī, al-Ma'rifa wa-lta'rīkh, ed. Akram Ḍiyā' al-'Umarī (Beirut: al-Risāla, 1401/1981), 1:137) more or less coincided with Ibn Ishạāq's death.

24 Mas'ūdī, Murūjal-dhahab, ed. Ch. Pellat (Beirut: al-Jāmi'a al-Lubnāniyya, 1966-1979), 5:211, no. 3446 . 
ing in Egypt in 115/733. In his home country he completed his biography of the Prophet, which is therefore wholly based on the Medinan tradition [...]. He presented a copy of his work to the caliph al-Manșūr in al-Hāshimiyya [...]". In a footnote Brockelmann remarked: "The report in al-Khațib that he wrote this work on the order of the caliph for the crown prince al-Mahdī, before later abbreviating it, must be a myth [...]."

\section{Appendix I: Ibn Sa'd's Abridged Entry on Ibn Isḥāq}

Ibn Sacd, al-Ṭabaqāt al-kubrā (Beirut: Dār Șādir-Dār Bayrūt, 138o/196o-1388/ 1968), 7:321-322; Ibn Sa'd, Kitāb al-Ṭabakāat al-kabìr, viı/ii, ed. Eduard Sachau (Leiden: Brill, 1918), 67:

The passage in bold includes the list of those who transmitted hadith from Ibn Isḥāq, including Ibrāhīm b. Sacd. It is missing in the fuller entry (Appendix II) because of a scribal error: the passage begins with wa-kāna and the scribe's eye strayed to the following occurrence of wa-kāna:

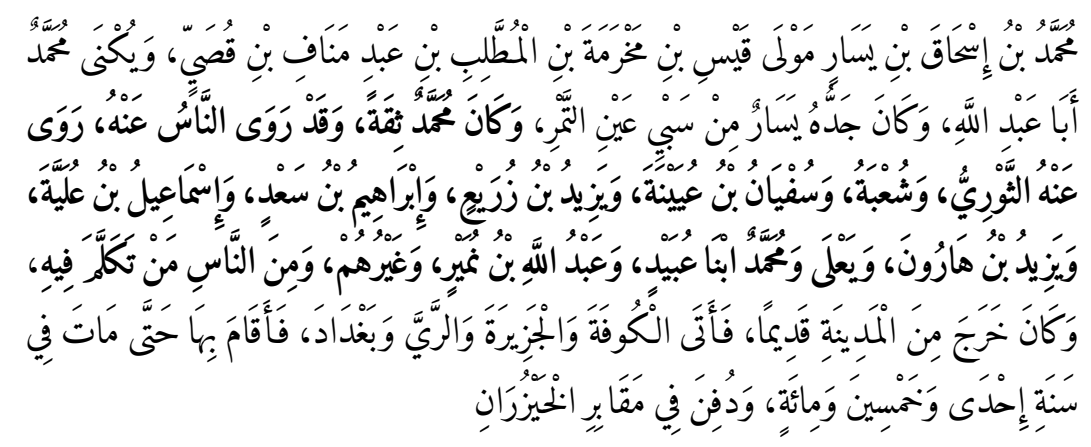

Ibn Sa'd, al-Ṭabaqāt al-kubrā: al-qism al-mutammim li-tābiči ahl al-Madīna waman ba'dahum, ed. Ziyād Muhammad Manșūr (Medina: Maktabat al-'Ulūm wa-l-Ḥikam, 1408/1987), 400-402; Ibn Sa`d, Kitāb al-țabaqāt al-kabìr, ed. 'Alī Muhammad 'Umar(Cairo: Khānjī, 1421/20o1), 7:552-553; http://shamela.ws/rep .php/book/1126:

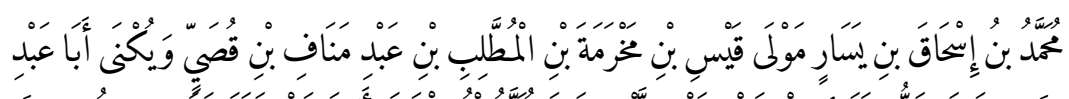

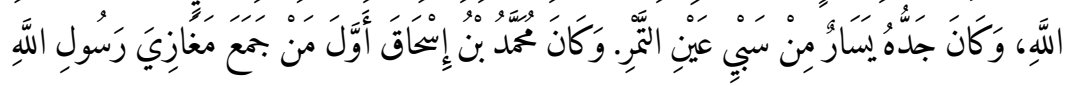




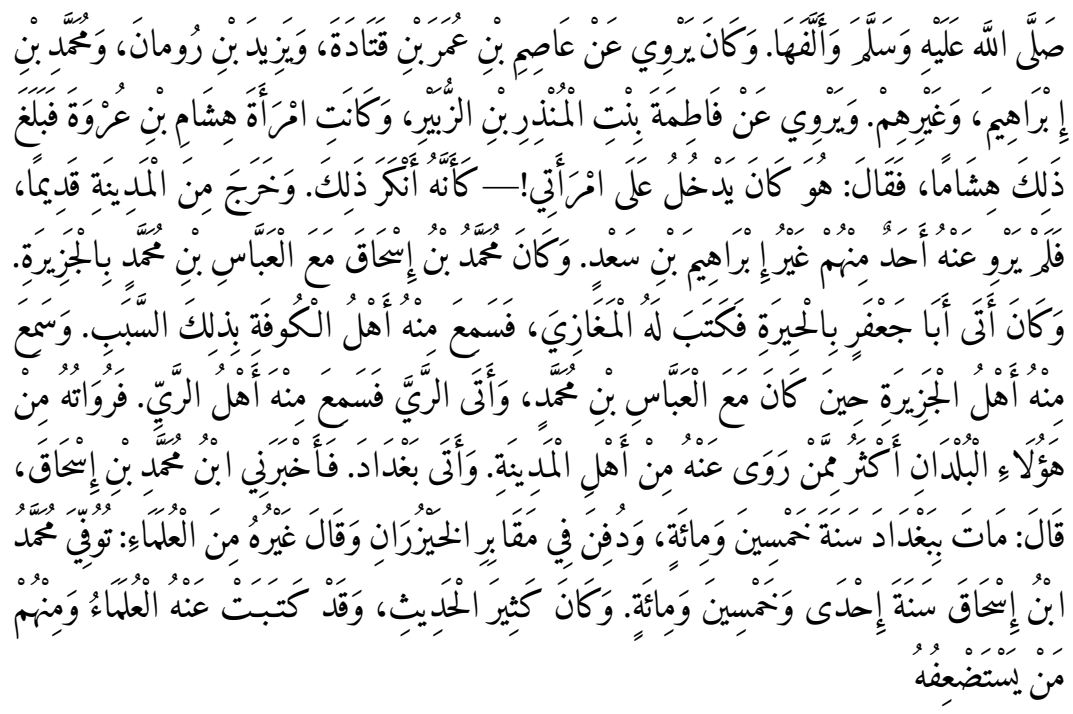

The original owner of Ibn Sa'd's walā' was al-Husayn b. 'Abd Allāh b. 'Ubayd Allāh b. al-'Abbās (d. 140/757 or 141/758). ${ }^{25}$ Al-Husayn was one of Ibn Ishāà's many informants. ${ }^{26}$ Ibn Ishạa quoted from him, for example, the account of the alleged secret conversion to Islam of 'Abbās, his wife and his slave Abū Rāfic who was the supposed source of the account (kuntu ghuläman li-l-'Abbās ...).

The Abbasid caliphs descended from 'Ubayd Allāh's brother 'Abd Allāh. Through his walä' Ibn Sa'd had an even closer link with the ruling line of the Banū Hāshim. Al-Husayn's son, 'Abd Allāh, who presumably inherited Ibn Sa'd's wala', was married to a member of the ruling line, namely Umm 'İsā al-ṣughrā (i.e. the younger of the two sisters each of whom was called Umm 'Īsā) bt. 'Alī b. 'Abd Allāh b. al-'Abbās (d. unknown). They had no children and when he died, she received his inheritance together with his 'așaba or male relations. Umm 'Īsā's brother Muhammad was "the father of the caliphs" (abū alkhalāif $){ }^{27}$

25 Johann Wilhelm Fück, "Ibn Sa'd," in Encyclopaedia of Islam, 2nd ed., accessed 1 October 2017, http://dx.doi.org/10.1163/1573-3912_islam_SIM_3343. Mizzī, Tahdhīb al-kamāl, 25:258; Ibn Sa'd, al-Tabaqāt al-kubrā (Beirut: Dār Șādir-Dār Bayrūt, 138o/196o-1388/1968), 5:315.

26 Mizzī, Tahdhīb al-kamāl, 6:384.

27 Muṣ́ab al-Zubayrī, Nasab Quraysh, ed. Évariste Lévi-Provençal (Cairo: Dār al-Macārif, 1953), 29-30; Ibn Sa'd, al-Tabaqāt al-kubrā, 5:313. 


\section{Acknowledgements}

The argument was presented in soAs on the 1oth of April 2015 at a workshop held in honour of Prof. Gerald Hawting. I am indebted to Prof. Michael Cook for giving me the green light. Also to my colleague, Dr. Joseph Witztum, for helpful comments on the draft.

\section{Bibliography}

Aḥmad b. Ḥanbal. al-Tlal wa-ma'rifat al-rijāl riwāyat ibnihi Abdallāh, edited by Wașī Allāh b. Muḥammad 'Abbās. Riyadh: Dār al-Khānī, 1422/2001.

Aḥmad b. Hanbal. Min kaläm Aḥmad ibn Hanbal fì 'ilal al-hadìth wa-ma'rifat al-rijäl, edited by Ṣubḥī al-Badrī al-Sāmarrā̄ì. Riyadh: Maktabat al-Macārif, 1409.

Anthony, Sean. "Muhammad, Menahem, and the Paraclete: New Light on Ibn Isḥāq's (d. 150/767) Arabic Version of John 15:23-16:1." Bulletin of the School of Oriental and African Studies 79 (2016): 255-278.

Dhahabī. Siyar a'lām al-nubalā', edited by Shu'ayb al-Arnāwūṭ et al. Beirut: al-Risāla, 1401/1981-1409/1988.

Elad, Amikam. "Community of Believers of 'Holy Men' and 'Saints' or Community of Muslims? The Rise and Development of Early Muslim Historiography." Journal of Semitic Studies 47 (2002): 241-308.

Elad, Amikam. "The Beginnings of Historical Writing by the Arabs: The Earliest Syrian Writers on the Arab Conquests." Jerusalem Studies in Arabic and Islam 28 (2003): 65-152. His articles are also available at https://huji.academia.edu/AmikamElad.

Fasawī. al-Ma'rifa wa-l-ta’’̄̄kh, edited by Akram Ḍiyā’ al-'Umarī. Beirut: al-Risāla, 1401/ 1981.

Fück, Johann Wilhelm. "Ibn Sa'd." In Encyclopaedia of Islam, and edition, edited by P. Bearman, Th. Bianquis, C.E. Bosworth, E. van Donzel and W.P. Heinrichs. Accessed 1 October 2017. http://dx.doi.org/10.1163/1573-3912_islam_SIM_3343.

Goldziher, Ignaz. Muslim Studies, edited by Samuel Miklos Stern, translated by C. Renate Barber and Samuel Miklos Stern. London: George Allen \& Unwin, 1967-1971.

Horovitz, Josef. The Earliest Biographies of the Prophet and their Authors, edited by Lawrence I. Conrad. Princeton: Darwin Press, 2002.

Ibn 'Asākir. Ta’rīkh madīnat Dimashq, edited by 'Umar b. Gharāma al-'Amrawī. Beirut: Dār al-Fikr, 1415/1995-1421/200o.

Ibn Farḥūn al-Mālikī. al-Dībāj al-mudhahhab fì ma'rifat a'yān 'ulamā' al-madhhab, edited by Ma’mūn al-Jannān. Beirut: Dār al-Kutub al-'Ilmiyya, 1417/1996.

Ibn Sa'd. Kitäbal-Tabakātal-kabìr, no. 7 (2), edited by Eduard Sachau. Leiden: Brill, 1918. Ibn Sa`d. al-Ṭabaqāt al-kubrā. Beirut: Dār Ṣādir-Dār Bayrūt, 138o/196o-1388/1968. 
Ibn Sa'd. Kitāb al-Ṭabaqāt al-kabìr, edited by 'Alī Muhammad 'Umar. Cairo: Khānjī, $1421 / 2001$.

Ibn Sa'd. al-Ṭabaqāt al-kubrā: al-qism al-mutammim li-tābici ahl al-Madīna wa-man ba'dahum, edited by Ziyād Muḥammad Manșūr. Medina: Maktabat al-'Ulūm wa-lHikam, 1408/1987.

al-Iṣfahānī, Abū l-Faraj. Kitāb al-Aghānī. Cairo: Dār al-Kutub, 1345/1927-1394/1974.

al-Khațīb al-Baghdādī. Ta’rīkh Baghdād, edited by Bashshār 'Awwād Macrūf. Beirut: Dār al-Gharb al-Islāmī, 1422/2001.

Kister, Meir Jacob. "The Massacre of the Banū Qurayẓa: A Re-examination of a Tradition." Jerusalem Studies in Arabic and Islam 8 (1986): 61-96.

Kister, Meir Jacob. "The Sïra Literature." In The Cambridge History of Arabic Literature: Arabic Literature to the End of the Umayyad Period, edited by Alfred Felix Landon Beeston, Thomas Muir Johnstone, Robert Bertram Serjeant and Gerald Rex Smith, 352-367. Cambridge: Cambridge University Press, 1983.

Lecker, Michael. "Wāqidī's Account on the Status of the Jews of Medina: A Study of a Combined Report." Journal of Near Eastern Studies 54 (1995): 15-32.

al-Ma'arrī, Abū l-'Alā'. Risālat al-ghufrān, edited by Bint al-Shāți'. Cairo: Dār al-Macārif, 1950.

Mas'ūdī. Murūj al-dhahab, edited by Charles Pellat. Beirut: al-Jāmía al-Lubnāniyya, 1966-1979.

Mizzī. Tahdhīb al-kamāl, edited by Bashshār 'Awwād Márūf. Beirut: al-Risāla, 1405/ $1985^{-1413 / 1992 .}$

Munt, Harry. "Writing the History of an Arabian Holy City: Ibn Zabāla and the First Local History of Medina." Arabica 59 (2012): 1-34.

Raven, Wim. "Biography of the Prophet." In Encyclopaedia of Islam, THREE, edited by Kate Fleet, Gudrun Krämer, Denis Matringe, John Nawas and Everett Rowson. Accessed 1 October 2017. http://dx.doi.org/10.1163/1573-3912_ei3_COM_23716.

Schoeler, Gregor. The Biography of Muhammad: Nature and Authenticity. New York and London: Routledge, 2011.

Țabarī. Ta'rīkh al-rusul wa-l-mulūk, edited by Michael Jan de Goeje et al. Leiden: Brill, 1879-19o1.

al-Ṭarābīshī, Muṭāé. Ruwāt Muḥammad ibn Isḥāq ibn Yasār fì l-maghāzī wa-l-siyar wasā’ir al-marwiyyāt. Beirut: Dār al-Fikr al-Mu'āṣir \& Damascus: Dār al-Fikr, 1414/1994. Zaman, Muhammad Qasim. Religion and Politics under the Early 'Abbāsids: The Emergence of the Proto-Sunnī Elite. Leiden: Brill, 1997.

al-Zubayrī, Muṣ‘ab. Nasab Quraysh, edited by Évariste Lévi-Provençal. Cairo: Dār alMa`ārif, 1953. 